\title{
Plasma Amino Acids in Dogs with Osteochondrosis or Hip Dysplasia
}

Radiography of the hip joints of mature dogs has shown that hip dysplasia is quite common in many middle and large size breeds in Norway. The heritability of hip dysplasia has been estimated in several studies to be between 0.2 and 0.6 (Hedhammar et al. 1979). This indicates that environmental factors are important for development and severity of hip dysplasia.

Nutrition, as it affects growth rate, is an important environmental factor. It has been shown that cesarean-delivered, hand-reared pups on low caloric intake had a lower frequency of hip dysplasia than did normally delivered, bitchfed pups (Lust et al. 1973), and that weaned pups on a low caloric intake had a lower frequency and less severe hip dysplasia than was the case for littermates kept on high caloric intake (Kasstrøm 1975).

Lust et al (1972) made biochemical and ultrastructural studies of articular cartılage in normal dogs and dogs with hip dysplasia. They found that dogs with hip dysplasia showed abscence of large collagen fibrils, disoriented collagen fibers and irregular periodicity of the collagen fibers. It was also found that the collagen synthesis was markedly reduced in the cartilage of dogs with hip dysplasia.

Resnick (1974) found that pups fed an allmeat diet developed normal hips, while other pups from the same litter fed a highcarbohydrate diet developed hip dysplasia. This result indicates that meat contain substances of which some dogs need a certain amount for normal hip joint development. This could be collagen, containing proline, hydroxyproline, alanine, lysine, hydroxylysine, glycine and arginine (Mınor 1980). It has been argued that osteochondrosis and hip dysplasia are different signs of the same malady (Milton 1983).

On this background we have measured plasma concentrations of amino acids in dogs with osteochondrosis and hip dysplasia. The material consisted of dogs of different middle and large size breeds. The control group was composed of dogs without signs or history of lameness or disease, the osteochondrosis group of dogs that had osteochondrosis in one or both shoulder joints, and the hip dysplasia group of dogs showing either middle or severe hip dysplasia. The diagnoses were determined by radiography. Blood samples were taken in heparin tubes from a brachial vein in the middle of the day, before the dogs were fed their main meal. The blood was centrifuged and the plasma specimens were frozen at $-20^{\circ} \mathrm{C}$ until analysis. The amino acid analyses of the plasma samples were performed by a Biotronik amino acid analyser (Perry et al 1968). The chromatograms were integrated by a Spectra Physic 4270 integrator, calibrated by a standard amino acid solution in 3 different dilutions.

The results presented in Table 1 show no differences between normal dogs and dogs with hip dysplasia or osteochondrosis with respect to proline, hydroxyproline, alanine, lysine, arginine and glycine content in the 
Table 1. Amino acid concentrations in plasma from normal dogs with osteochondrosis and hip dysplasia (average and standard deviation, $\mu \mathrm{mol} / \mathrm{l}$ ). Differences between groups tested with one-way analysis of variance.

\begin{tabular}{lcccccccc}
\hline Group & $\mathrm{n}$ & $\begin{array}{c}\text { Age in } \\
\text { months }\end{array}$ & Proline & $\begin{array}{c}\text { Hydroxy- } \\
\text { prolıne }\end{array}$ & Alanıne & Lysine & Argınıne & Glycıne \\
\hline $\begin{array}{l}\text { Control } \\
\begin{array}{l}\text { Hip } \\
\text { dysplasia }\end{array}\end{array}$ & 5 & $8.4 \pm 2.6$ & $276 \pm 121$ & $63 \pm 40$ & $367 \pm 170$ & $169 \pm 81$ & $143 \pm 42$ & $288 \pm 66$ \\
$\begin{array}{l}\text { Osteo- } \\
\text { chondrosis }\end{array}$ & 11 & $8.3 \pm 2.0$ & $306 \pm 207$ & $97 \pm 56$ & $489 \pm 170$ & $163 \pm 66$ & $124 \pm 19$ & $352 \pm 144$ \\
\hline & & $\mathrm{F}=0.01$ & $\mathrm{~F}=0.28$ & $\mathrm{~F}=1.56$ & $\mathrm{~F}=313$ & $\mathrm{~F}=0.19$ & $\mathrm{~F}=0.88$ & $\mathrm{~F}=0.89$ \\
& $2 / 12$ & $2 / 23$ & $\begin{array}{c}2 / 20 \\
\text { n.s. }\end{array}$ & $\begin{array}{c}2 / 23 \\
\text { n.s. }\end{array}$ & $\begin{array}{c}2 / 23 \\
\text { n.s. }\end{array}$ & $\begin{array}{c}2 / 23 \\
\text { n.s. }\end{array}$ & $\begin{array}{c}2 / 23 \\
\text { n.s. }\end{array}$ \\
\hline
\end{tabular}

plasma. Neither were significant differences found between the 3 groups for 21 other amino acids. This indicates that amino acid deficiencies or dysfunctions in collagen metabolism hardly can be involved in the pathogenesis of canine osteochondrosis and hip dysplasia.

\section{Acknowledgement}

We thank Dr. Berit Krohn for supplying material to the study, and Dr. Howard Parker for help with the manuscript.

\section{Ingolf Hanssen}

Strinda Small Anımal Clinıc,

Tronherm, Norway and

Department of Laboratory Animals,

University Hospital of Trondheim,

Trondheim, Norway.

Hilde Lunde and Leiv $R$ Gjessing

Dikemark Hospital, Asker,

Solberg, Norway.

\section{References}

Hedhammar A, Olsson S-E, Andersson S, Persson $L$, Pettersson L, Olausson A, Sundgren P-E Canıne hıp dysplasia: Study of heretability in 401 litters in German Shepherd dogs. J. Amer. vet. med. Assoc. 1979, 174, 1012-1016.

Kasstrom $H$ Nutrition, weight gain and development of hip dysplasia. Acta radiol. 1975. Suppl. 344, 135-179.

Lust G, Pronsky $W$, Sherman DM Biochemical and ultrastructural observations in normal and degenerative canine articular cartilage. Amer. J. vet. Res. 1972, 33, 2429-2440.

Lust G, Geary JC, Sheffy BE Development of hip dysplasia in dogs. Amer. J. Vet. Res. 1973, 34, 87-91.

Multon $J L$ Osteochondrosis dissecans in the dog. In Vet. Clin. North Amer.: Small Anım. Pract. 1983.

Minor RR Collagen metabolism. Amer. J. Pathol. 1980, 98, 227-279.

Perry TL, Stedman D, Hansen $S \cdot$ A versatile lithium buffer elution system for single column automatic amino acid chromatography. J. Chromatogr. 1968, 38, 460-466.

Resnick $S$ Effect of an all-meat diet and a high carbohydrate diet on hip formation in dogs. Vet. Med./Small Anim. Clin. 1974, 69, 739743.

(Received June 30, 1988, accepted Aprll 17, 1989)

Reprints may be requested from: Ingolf Hanssen, Strinda Small Anımal Clinic, P. O. Box 5823, N-7002 Trondheim, Norway. 